\title{
Pengaruh Mobilisasi Dan Fisioterapi Dada Terhadap Kejadian Ventilator Associated Pneumonia Di Unit Perawatan Intensif
}

\author{
Hendra $^{a}$, Emil Huriani ${ }^{\mathrm{b}}$ \\ ${ }^{\text {a }}$ RS.Dr.M.Djamil Padang \\ ${ }^{\mathrm{b}}$ Program Studi Ilmu Keperawatan Fakultas Kedokteran Universitas Andalas \\ Email : hendra200954@yahoo.co.id
}

\begin{abstract}
Incidence of Ventilator Associated Pneumonia (VAP) in patients who mounted mechanical ventilation in the Intensive Care Room RS. Dr. M. Djamil was increase, in terms of mobilization for the implementation of mobilization (ambulation) and chest physiotherapy have been prepared in accordance with standard operational procedure (SOP). Presumably this is caused by not all of the implementation of measures given to patients in accordance with SOP. The purpose of this study was to investigate the effect of mobilization (ambulation) and chest physiotherapy on the incidence of VAP in patients who mounted ventilator in intensive care hospital. Dr. M. Djamil Padang. This Quasy-experimental study used static group comparison design, with the number of respondents as many as 20 people. Data analysis was conducted using the Mann-Whitney test. The results showed decreased incidence of VAP in the experimental group, but no significant differences between the experimental group and control group with $p$-value $=0189$. Need to increase the implementation of mobilization (ambulation) and chest physiotherapy on patients who mounted ventilators to prevent Ventilator Associated Pneumonia (VAP).
\end{abstract}

Keywords: mobilization, chest physiotherapy, Ventilator Associated Pneumonia (VAP), mechanical ventilation.

\begin{abstract}
Abstrak : Kejadian Ventilator Associated Pneumonia (VAP) pada pasien yang terpasang ventilasi mekanik di Ruang Perawatan Intensif RS. Dr. M. Djamil terjadi peningkatan, padahal untuk tindakan mobilisasi (ambulasi) dan fisioterapi dada telah disusun standar operasional prosedur (SOP). Diduga hal ini disebabkan oleh pelaksanaan SOP yang tidak sepenuhnya. Tujuan penelitian ini untuk melihat pengaruh mobilisasi (ambulasi) dan fisioterapi dada terhadap kejadian VAP pada pasien yang terpasang Ventilator di ruang perawatan intensif RS. Dr. M. Djamil Padang. Penelitian Kuasi-eksperimen ini menggunakan rancangan perbandingan kelompok statis, dengan jumlah responden sebanyak 20 orang. Analisa yang dilakukan menggunakan uji Mann-Whitney. Hasil penelitian menunjukan penurunan kejadian VAP pada kelompok eksperimen, namun tidak ada perbedaan yang bermakna antara kelompok eksperimen dan kelompok kontrol dengan nilai $\mathrm{p}=0.189$. Perlu peningkatan pelaksanaan mobilisasi (ambulasi) dan fisioterapi dada terhadap pasien yang terpasang ventilator untuk mencegah terjadinya Ventilator Associated Pneumonia (VAP).
\end{abstract}

Kata Kunci : mobilisasi, fisioterapi dada, Ventilator Associated Pneumonia (VAP), ventilasi mekanik.

Pneumonia adalah suatu penyakit infeksi atau peradangan pada organ paruparu yang disebabkan oleh bakteri, virus, jamur ataupun parasit di mana alveoli paru yang bertanggung jawab menyerap oksigen dari atmosfer dan terisi oleh cairan. 
Pneumonia dapat juga disebabkan oleh iritasi kimia atau fisik dari paru-paru atau sebagai akibat dari penyakit lainnya, seperti kanker paru-paru atau terlalu banyak minum alkohol. Namun penyebab yang paling sering ialah serangan bakteri streptococcus pneumoniae atau pneumokokus (Brunner \& Suddarth, 2002).

Pneumonia terdiri dari dua macam, yaitu: Pneumonia yang didapat dari masyarakat atau Community Acquired Pneumonia (CAP) dan Pneumonia yang didapat dari dalam rumah sakit atau Hospital Acquired Pneumonia (HAP). Pneumonia nosokomial merupakan salah satu komplikasi perawatan di rumah sakit yang meningkatkan morbiditas dan mortalitas pasien. Insiden pneumonia nosokomial mencapai 30\%. Pneumonia nosokomial yang terjadi dirumah sakit dapat dibagi dua, yaitu: Hospital Acquired Pneumonia (HAP) dan Ventilator Associated Pneumonia (VAP). Kedua jenis pneumonia ini masih jadi penyebab penting dalam angka kematian dan kesakitan pada pasien yang dirawat dirumah sakit (Sedono, 2007).

VAP terjadi pada klien yang menggunakan ventilasi mekanik dan intubasi. Kuman penyebab infeksi ini tersering adalah bakteri gram negatif (Dahlan, 2006). Rekam medik Intensive Care Unit (ICU) Rumah Sakit St.Borromeus Bandung mencatat angka kejadian infeksi nosokomial pneumonia 24\% dengan angka mortalitas 33,33\% (Regina, 2006). Rekam medik Rumah Sakit Hasan Sadikin Bandung mencatat $47 \%$ infeksi nosokomial pneumonia pada pasien yang menggunakan ventilasi mekanik dan intubasi (Dahlan, 2006). Insiden nosokomial pneumonia di Rumah Sakit Dr. M. Djamil Padang pada klien yang menggunakan ventilasi mekanik dan intubasi 15\% - 59\% (Saanin, 2006).

VAP terjadi lebih dari 48 jam setelah pasien di intubasi dan terpasang ventilasi mekanik (Koenig, 2006). Pada saluran napas bagian atas akan terjadi kolonisasi mikroorganisme beberapa jam setelah intubasi, diantara mikroorganisme tersebut paling sering dijumpai Pseudomonas aeroginosa dan Staphylococcus aureus. VAP sering terjadi karena pipa endotrakeal atau trakeostomi memungkinkan bagian bebas dari bakteri masuk ke dalam paruparu, bakteri juga dibawa melalui penghisapan (suctioning) dan bronkoskopi (Kollef, 2008).

Dalam pencegahan VAP dapat dilakukan dengan dua cara, yaitu: strategi non farmakologi dan strategi farmakologi. Dalam strategi non farmakologi, yaitu: mencuci tangan dan menggunakan sarung tangan, pelindung muka atau masker, posisi pasien dengan setengah duduk, menghindari pemberian nutrisi enteral dengan volume besar, intubasi oral, pemeliharaan sirkuit ventilator, penghisapan sekret dan perubahan posisi pasien miring kiri, telentang, miring kanan. Sebaliknya, strategi farmakologi diantaranya, yaitu: pemberian antibiotik (Sedono, 2007).

Pasien sakit kritis, pasien tak stabil yang memerlukan terapi intensif, mengalami gagal nafas berat, pasien bedah jantung, bedah thorak merupakan indikasi untuk masuk Intensive Care Unit (ICU). Pasien masuk ke ruang Intensif juga memerlukan pemantauan intensif invasif dan non invasif. ICU merupakan tempat atau unit tersendiri di dalam rumah sakit yang menangani pasien-pasien gawat karena penyakit, trauma atau komplikasi penyakit lain. Peralatan standar di Intensive Care Unit (ICU) meliputi ventilasi mekanik untuk membantu usaha bernafas melalui endotracheal tubes atau trakheostomi (Murdiyanto, 2009).

Ventilasi mekanik adalah alat bantu napas bertekanan positif atau negatif yang dapat mempertahankan ventilasi dan pemberian oksigen dalam waktu yang lama. Ventilasi mekanik sering digunakan sebagai profilaktik untuk mempertahankan oksigen dan eliminasi $\mathrm{CO}_{2}$ yang adekuat. Ventilasi mekanik juga merupakan terapi definitif pada pasien kritis yang mengalami hipoksemia dan hiperkapnea. Tenaga 
keperawatan harus memahami prinsipprinsip dan cara pemasangan ventilasi mekanik, operasional pemakaian alat dan perawatan ventilasi mekanik (Dudut, 2003).

Tindakan perawatan ventilasi mekanik merupakan salah satu aspek kegiatan perawat dalam memberikan asuhan keperawatan sehari-hari di ruang intensif dalam fungsi independen dan interdependen dengan tim medis. Dalam tindakan perawatan ventilasi mekanik perawat harus berhati-hati karena mempunyai resiko yang besar seperti terjadinya infeksi nosokomial pneumonia (Hudak, 1997). Ventilasi mekanik memberikan tekanan positif secara kontinu yang dapat meningkatkan pembentukan sekresi pada paru-paru. Perawat harus mengidentifikasi adanya sekresi dengan cara auskultasi paru sedikitnya 2-4 jam (selama pasien masih terpasang ventilasi mekanik dan post ekstubasi). Tindakan untuk membersihkan jalan napas diantaranya yaitu: fisioterapi dada seperti penepukkan pada dada/punggung, menggetarkan, perubahan posisi, seperti; posisi miring, posisi telentang, fisioterapi dada, dan termasuk penghisapan (Dudut, 2003).

Fisioterapi dada sangat berguna bagi penderita penyakit paru baik yang bersifat akut maupun kronis, sangat efektif dalam upaya mengeluarkan sekret dan memperbaiki ventilasi pada pasien dengan fungsi paru yang terganggu. Jadi tujuan pokok fisioterapi pada penyakit paru adalah mengembalikan dan memelihara fungsi otot-otot pernafasan dan membantu membersihkan sekret dari bronkhus dan untuk mencegah penumpukan sekret. Fisioterapi dada ini dapat digunakan untuk pengobatan dan pencegahan pada penyakit paru obstruktif menahun, penyakit pernafasan restriktif karena kelainan neuromuskuler dan penyakit paru restriktif karena kelainan parenkim paru seperti fibrosis dan pasien yang mendapat ventilasi mekanik (Afiyah, 2009).

Mobilisasi atau aktivitas di rumah sakit pada pasien istirahat total sangat penting sekali dilakukan. Mobilisasi terdiri dari Range Of Motion (ROM) dan Ambulasi. Komplikasi dari lamanya tirah baring salah satunya perubahan pada paru akan terjadi atelektasis dan pneumonia (Potter \& Perry, 2006).

Data ruangan Intensive Care Unit (ICU) dari bulan Juli 2007 sampai dengan Juni 2010 menunjukkan peningkatan angka kejadian VAP yaitu $13,0 \%$ pada periode bulan Juli 2007 sampai Juni 2008, 15,5\% pada periode bulan Juli 2008 sampai Juni 2009 dan 14,4\% pada periode bulan Juli 2009 sampai Juni 2010 VAP (Medical Record dan Buku Register/Laporan ruangan ICU RS.Dr.M.Djamil Padang). Angka kejadian VAP ini tidak termasuk pasien yang saat masuk telah didiagnosa Penyakit Paru Obstruksi Menahun (PPOM), dan Tuberculosis Paru (TB Paru).

Observasi yang dilakukan di Unit Perawatan Intensif pada tanggal 3 September 2010 mengenai upaya perawat dalam pencegahan nosokomial pneumonia. Peneliti menemukan 6 orang dari 11 perawat yang dipilih secara acak yang kurang melakukan tindakan upaya pencegahan nosokomial pneumonia, antara lain 3 orang tidak melakukan cuci tangan sebelum tindakan, 3 orang melakukan penghisapan lendir tidak sesuai SOP. Semua perawat telah mendapat pelatihan dasar ICU, perawatan ventilasi mekanik dan teknik suction dan 3 orang yang telah mendapat pelatihan khusus yaitu pelatihan ICU dewasa. Standar Operasional Prosedur (SOP) tindakan pencegahan nosokomial pneumonia di ruang perawatan Intensif Rumah Sakit Dr. M. Djamil Padang sudah ada, tapi hanya sebagian perawat yang melaksanakan karena disebabkan oleh berbagai faktor, diantaranya; jumlah ketenagaan yang kurang, kondisi penyakit pasien dan cara kerja tidak sesuai dengan prosedur yang ada.

Sebelumnya telah dilakukan penelitian tentang hubungan pengetahuan dan sikap perawat dengan tindakan pencegahan Ventilator Associated 
Pneumonia (VAP) oleh Yuldanita tahun 2008 di Unit Perawatan Intensif RS Dr. M. Djamil Padang terhadap 25 orang responden, didapatkan hasil perawat yang mempunyai pengetahuan tinggi tentang tindakan pencegahan Ventilator Asociated Pneumonia (VAP) berjumlah 15 orang (60\%) dan yang mempunyai pengetahuan rendah 10 orang $(40 \%)$. Menurut Dudut (2003), tenaga perawat harus memahami dan mempunyai pengetahuan tentang prinsip-prinsip dan cara pemasangan ventilasi mekanik, operasional pemakaian alat dan perawatan ventilasi mekanik. Menurut Hudak (1997), dalam tindakan perawatan ventilasi mekanik perawat harus berhati-hati karena mempunyai resiko yang besar seperti terjadinya infeksi nosokomial pneumonia.

Tujuan penelitian ini adalah untuk menganalisa pengaruh mobilisasi dan fisioterapi dada terhadap kejadian Ventilator Associated Pneumonia (VAP) pada pasien terpasang ventilasi mekanik.

\section{METODE}

Penelitian ini menggunakan rancangan penelitian kuasi eksperimen dengan rancangan perbandingan kelompok statis (posttest only control group design) Kelompok eksperimen menerima perlakuan sesuai dengan SOP, sedangkan kelompok pembanding diberikan perlakuan sesuai dengan kebiasaan ruangan. Kegiatan pengumpulan data dilakukan pada bulan Maret - April 2011, bertempat di Unit Perawatan Intensif Rumah Sakit Umum Pusat Dr. M. Djamil Padang. Sampel dalam penelitian ini adalah 20 pasien yang terpasang ventilasi mekanik, minimal 2 hari setelah dilakukan intubasi di Unit Perawatan Intensif Rumah Sakit Umum Pusat Dr. M. Djamil Padang yang dibagi menjadi 10 orang pada masing-masing kelompok intervensi dan kelompok pembanding. Semua responden adalah pasien yang terpasang ventilator hari pertama dan sebelumnya tidak ada kelainan/infeksi paru yang ditandai saat auskultasi tidak ada ronkhi, serta hasil pemeriksaan leukosit darah dalam rentang normal. Pasien yang mengalami penyakit paru seperti; PPOK, kanker paru, TB paru dan trauma pada paru tidak menjadi responden dalam penelitian ini.

Variabel dependen dalam penelitian ini adalah pelaksanaan mobilisasi dan fisioterapi dada, sedangkan variabel independen adalah kelompok yang dilakukan mobilisasi (ambulasi) dan fisioterapi dada sesuai dengan SOP dan kelompok yang dilakukan mobilisasi dan fisioterapi dada sesuai dengan kebiasaan ruangan. Mobilisasi didefinisikan menjadi penggantian posisi pasien setiap dua jam yaitu, miring kiri, telentang dan miring kanan. Fisioterapi dada adalah tindakan yang dilakukan pada pasien dengan cara menepuk dinding dada atau punggung dengan tangan dibentuk seperti mangkok dilanjutkan vibrasi dengan cara menggetarkan dinding dada atau punggung pada waktu pasien mengeluarkan napas.

Kejadian VAP ditandai dengan adanya infeksi pada paru terutama Lobus paru bagian bawah yang terjadi akibat pemasangan ventilasi mekanik dan setelah $>48$ jam intubasi. Positif bila pada pemeriksaan fisik fungsi pernapasan ditemukan ronkhi (+) dan frekuensi napas meningkat, hasil radiology ditemukan infiltrat (+) lobus paru bagian bawah dan hasil pemeriksaan laboratorium pada leukosit darah $>10.000$. Kritaria terakhir adalah hasil kultur sputum terinfeksi. Kejadian VAP dinilai pada hari ketiga pemasangan ventilasi mekanik.

Analisa univariat dilakukan untuk mengetahui distribusi frekwensi kejadian VAP pada pasien yang terpasang ventilasi mekanik. Untuk mengetahui pengaruh intervensi, dilakukan dengan uji MannWhitney. Untuk melihat hasil kemaknaan perhitungan statistik digunakan batas kemaknaan 0,05, dimana jika nilai $\mathrm{p}>0,05$ maka hasil hitungan disebut tidak bermakna. 


\section{HASIL DAN PEMBAHASAN}

Berdasarkan tabel 1 didpatkan responden kelompok kontrol sebagian besar berumur antara 20 - 39 tahun sebanyak 5 orang $(50 \%)$, dan sebagian kecil berumur antara $60-79$ tahun sebanyak 1 orang (10\%) (Tabel 1). Disisi lain, responden kelompok intervensi sebagian besar berumur antara $40-59$ tahun sebanyak 5 orang $(50 \%)$, dan sebagian kecil berumur antara $20-39$ tahun sebanyak 2 orang (20\%). Jumlah responden yang berjenis kelamin laki-laki dan perempuan dari kelompok kontrol dan intervensi adalah sama yaitu: laki-laki sebanyak 7 orang (70\%), dan perempuan sebanyak 3 orang (30\%). Responden pada kelompok kontrol yang diagnosa Post craniotomi didapatkan 7 orang $(70 \%)$, dan masing-masing 1 orang (10\%) dengan diagnosa Post Laparatomi, Post Thyroidectomi, dan gagal nafas. Sebaliknya, pada kelompok intervensi yang terbanyak adalah pasien dengan diagnosa post Laparatomi didapatkan 5 orang $(50 \%)$, dan masing-masing 2 orang (20\%) dengan diagnosa Post craniotomi dan Post Thyroidectomi, serta pasien dengan diagnosa Post Radikal sistostomi didapatkan 1 orang (10\%).

Perlakuan yang didapat oleh responden pada kelompok kontrol berdasarkan hasil observasi menunjukkan bahwa dalam melakukan tindakan mobilisasi (ambulasi) seperti miring ke kiri, dan miring ke kanan hanya sekali dalam sehari ketika pagi hari selesai memandikan pasien. Selanjutnya, tindakan fisioterapi dada dimulai bila sudah adanya tanda-tanda penumpukan sekret. Fisioterapi dada yang sering dilakukan hanya penepukan, dan penghisapan lendir. Fisioterapi dada dapat mengembalikan dan memelihara fungsi otot-otot pernafasan serta membantu membersihkan sekret pada bronkhus dan untuk mencegah penumpukan sekret pasien yang menggunakan ventilasi mekanik (Afiyah, 2009).

$\begin{array}{rrrr}\text { Potter } & \text { dan } & \text { Perry } & \text { (2006) } \\ \text { mengatakan } & \text { sekret } & \text { yang menetap }\end{array}$ menumpuk di bronkus dan paru menyebabkan pertumbuhan bakteri yang selanjutnya berkembang menjadi pneumonia. Infeksi pulmonal tetap berkembang meskipun dilakukan intervensi untuk pencegahannya. Sekret dapat dikurangi dengan mengubah posisi klien setiap 2 jam, sedangkan fisioterapi dada adalah metoda efektif untuk mencegah sekret pulmonal dan mengalirkan sekret dari segmen paru tertentu dari bronkus dan paru menuju trakhea.

Mobilisasi (ambulasi) yang dilakukan pada pasien yang terpasang ventilasi mekanik pada kelompok intervensi seperti posisi miring ke kiri, posisi telentang dan posisi miring ke kanan. Mobilisasi ini dilakukan setiap 2 jam sebanyak 3 kali sehari sebelum makan dan disesuaikan dengan jadwal makan pasien. Tujuan dari mobilisasi antara lain: mempertahankan fungsi tubuh, memperlancar peredaran darah, membantu pernapasan menjadi lebih baik, mempertahankan tonus otot, mengembalikan aktivitas tertentu sehingga pasien dapat kembali normal atau dapat memenuhi kebutuhan gerak harian (Suzan, 2004).

Pengaruh yang bisa terjadi akibat imobilisasi salah satunya pada sistem pernapasan, paru-paru akan terjadi atelektasis dan pneumonia. Perubahan posisi pasien minimal setiap 2 jam memungkinkan area paru untuk kembali mengembang. Pengembangan kembali mempertahankan elastisitas rekoil paru dan kebersihan area paru dari sekresi pulmonal. Posisi miring membantu menghilangkan tekanan pada punggung dan tumit untuk individu yang tidak dapat turun dari tempat tidur atau tirah baring (Potter \& Perry, 2006). 
Fisioterapi dada dilakukan pada waktu pertukaran dinas pagi ketika memandikan pasien seperti; penepukkan, menggetarkan, posisi drainase, dan penghisapan. Penepukkan dada meliputi pengetokan dinding dada dengan kedua tangan yang dibentuk seperti mangkok dengan memfleksikan jari tangan dan meletakkan ibu jari bersentuhan dengan jari telunjuk. Penepukkan dinding dada secara mekanis melepaskan sekret yang ada pada segmen paru. Posisi pasien tergantung pada segmen paru yang akan dilakukan penepukkan. Penepukkan dilakukan selama 3-5 menit setiap posisi.

Menggetarkan merupakan tindakan yang dilakukan dengan cara meletakkan tangan bertumpang tindih pada dada dengan dorongan bergetar dan dilakukan hanya pada waktu pasien mengeluarkan nafas atau saat ekspirasi. Tujuannya untuk mendorong keluar sekresi yang tertimbun dengan bantuan menggetarkan dinding thorak pada waktu batuk dan merangsang terjadinya batuk. Postural drainase (PD) merupakan salah satu intervensi untuk melepaskan sekresi dari berbagai segmen paru dengan menggunakan pengaruh gaya gravitasi. Tujuan dari posisi drainase ini supaya tidak terjadi penimbunan sekresi didalam paru-paru dan mencegah terjadinya collaps dari alveoli karena broncheolus tertutup sekresi. Indikasi posisi drainase: pasien sesudah operasi dengan retensi sputum, bronkho pneumonia, pasien tidak sadar, nafas dangkal dan reflek batuk tidak adekuat.

Penghisapan lendir merupakan suatu tindakan yang dilakukan untuk membersihkan jalan nafas dengan cara memasukan kateter suction melalui mulut, hidung atau jalan nafas (OTT,NTT,ETT). Tujuan dari penghisapan antara lain: untuk membebaskan jalan nafas, mengurangi retensi sputum, merangsang batuk, dan mencegah terjadinya infeksi paru.

Tabel 1.Distribusi Frekuensi Responden Berdasarkan Umur, jenis kelamin dan diagnosa medis pada kelompok kontrol dan kelompok intervensi di Ruang Rawat Intensif RSUP. Dr. M Djamil Padang

\begin{tabular}{lcccc}
\hline Karakteristik & $\begin{array}{c}\text { Kelompok Kontrol } \\
\text { Frekuensi }\end{array}$ & $\begin{array}{c}\text { Kelompok Intervensi } \\
\text { Persentase }\end{array}$ & $\begin{array}{c}\text { Frekuensi } \\
\text { Persentase }\end{array}$ \\
\hline Umur & 5 & 50 & 2 & 20 \\
$20-39$ tahun & 4 & 40 & 5 & 50 \\
$40-59$ tahun & 1 & 10 & 3 & 30 \\
60-79 tahun & & & & \\
Jenis Kelamin & 7 & 70 & 7 & 70 \\
Laki - laki & 3 & 30 & 3 & \\
Perempuan & & & & 20 \\
Diagnosa Medis & 7 & 70 & 2 & 50 \\
Post Craniotomi & 1 & 10 & 5 & 10 \\
Post Laparatomi & 0 & 0 & 1 & 20 \\
Post Radikal sistostomi & 1 & 10 & 2 & 0 \\
Post Thyroidectomi & 1 & 10 & 0 & \\
Gagal nafas & & & & \\
\hline
\end{tabular}

Tabel 2 memperlihatkan bahwa dari 10 orang kelompok kontrol terdapat sebagian besar $(70 \%)$ yang mengalami Ventilator Associated Pneumonia (VAP) positif, sedangkan pada kelompok intervensi terdapat sebagian besar $(60 \%)$ yang mengalami Ventilator Associated Pneumonia (VAP) negatif. Hasil uji statistik dengan melakukan uji Mann-Whitney didapatkan nilai $\mathrm{p}$ Value $=0,189(>0,05)$, 
berarti terlihat tidak ada perbedaan yang signifikan rata - rata kejadian Ventilator Associated Pneumonia (VAP) pada kelompok kontrol dan kelompok intervensi. Pada empat orang responden yang mengalami Ventilator Associated Pneumonia (VAP) positif, dua diantara responden yaitu lanjut usia, beberapa kemungkinan yang terjadi pada lanjut usia akan mengalami perubahan-perubahan fungsi, diantaranya meliputi keterbatasan ventilasi paru, dan tidak stabilnya vasomotor. Hospitalisasi dan tirah baring melapiskan beberapa faktor seperti menjadi imobilisasi dan kehilangan sensori (Potter \& Perry, 2006). Ada dua responden kelompok intervensi yang mengalami Ventilator Associated Pneumonia (VAP) positif terjadi karena diagnosa penyakit pasca operasi yang besar. Sebagian dari pneumonia nosokomial terjadi sesudah operasi, terutama bila ventilasi mekanik diperlukan paska bedah. Pasien dengan ventilator, misalnya mempunyai 6-12 kali resiko lebih tinggi mendapat pneumonia nosokomial dari pada pasien tanpa ventilator (Bossemeyer, 2004). Pada pasien bedah alasan utama untuk ventilasi mekanik adalah menurut jenis operasi, sedangkan pada pasien medik biasanya berhubungan dengan penyakit pasien, resiko pneumonia bacterial nosokomial pasca bedah jantung dan paru (misalnya by pass jantung dan reseksi paru) adalah 38 kali lebih besar dari operasi ditempat lain (CDC 1994 cit Tietjen, 2004).
Hasil penelitian dengan uji MannWhitney didapatkan hasil uji statistik dimana nilai $p=0,189 \quad(>0,05)$. Sesuai dengan aturan keputusan hipotesis statistik berarti Ha di tolak dan Ho di terima, berarti terlihat tidak ada perbedaan yang signifikan kejadian Ventilator Associated Pneumonia (VAP), antara mobilisasi (ambulasi) dan fisioterapi dada yang dilakukan sesuai dengan kebiasaan ruangan dengan mobilisasi (ambulasi) dan fisioterapi dada yang dilakukan sesuai dengan konsep teori. Tidak adanya perbedaan yang bermakna ini dapat terjadi karena pelaksanan tindakan mobilisasi (ambulasi) dan fisioterapi dada yang dilakukan sesuai dengan kebiasaan ruangan sudah sesuai dengan Standar Operasional Prosedur (SOP) Rumah sakit yang acuannya pada konsep dan teori yang sudah ada, tapi frekuensi tindakannya tidak sesuai dengan hasil yang diharapkan.

Pada penelitian ini secara uji statistik tidak ada perbedaan yang signifikan kejadian Ventilator Associated Pneumonia (VAP), antara kelompok kontrol dengan kelompok intervensi, namun demikian jumlah responden VAP ada penurunan pada kelompok intervensi dari 7 berkurang menjadi 4. Terjadi karena pelaksanan tindakan mobilisasi (ambulasi) dan fisioterapi dada yang dilakukan sesuai dengan kebiasaan ruangan sudah sesuai dengan Standar Operasional Prosedur (SOP) Rumah sakit yang acuannya pada konsep dan teori yang sudah ada.

Tabel 2.

Distribusi Frekuensi Responden Kejadian Ventilator Associated Pneumonia (VAP) pada kelompok kontrol dan kelompok intervensi di Ruang Intensif RSUP. Dr. M. Djamil Padang

\begin{tabular}{lcccc}
\hline Kejadian & \multicolumn{2}{c}{ Kelompok Kontrol } & \multicolumn{2}{c}{ Kelompok Intervensi } \\
VAP & Frekuensi & Persentase & Frekuensi & Persentase \\
\hline Positif & 7 & 70 & 4 & 40 \\
Negatif & 3 & 30 & 6 & 60 \\
Jumlah & 10 & 100 & 10 & 100 \\
\hline
\end{tabular}

Berdasarkan hasil penelitian di atas, maka peneliti menyimpulkan bahwa mobilisasi (ambulasi) dan fisioterapi dada dilakukan harus secara berurutan dimulai dari mobilisasi seperti miring kiri, telentang dan miring kanan, sedangkan fisioterapi dada dimulai dari penepukkan, menggetarkan, posisi drainase dan 
penghisapan lendir. Wahyuningsih (2005) berpendapat bahwa masalah yang disebabkan oleh imobilitas lama bisa menyebabkan infeksi pada paru, ketika pasien berbaring lama dan tidak bergerak akan terjadi penumpukan sekret didalam paru. Penumpukan ini mempermudah pertumbuhan bakteri dan dapat menyebabkan infeksi berat. Kemudian pendapat Afiyah (2009) fisioterapi dada dapat mengembalikan dan memelihara fungsi otot-otot pernafasan serta membantu membersihkan sekret pada bronkhus dan untuk mencegah penumpukan sekret pasien yang menggunakan ventilasi mekanik.

Kelemahan pada penelitian ini adalah distribusi responden menurut umur dan diagnosa medis tidak berimbang. Peneliti mengabaikan hal ini dengan pertimbangan keterbatasan waktu dalam pengumpulan data yang telah mencapai 2 bulan. Kelemahan pada distribusi jumlah responden berdasarkan umur, dapat dilihat pada tabel 2 dimana responden lanjut usia pada kelompok intervensi lebih banyak dari pada responden kelompok kontrol. Pada distribusi jumlah responden bardasarkan diagnosa medis, dapat dilihat pada tabel 4 bahwa responden kelompok kontrol yang diagnosa Post craniotomi lebih banyak dari pada responden kelompok intervensi dan diagnosa Post Laparatomi lebih banyak pada responden kelompok intervensi dari pada kelompok kontrol. Proporsi responden berdasarkan diagnosa medis pada kelompok kontrol dan intervensi berbeda. Sejauh ini belum ada literatur yang menjelaskan pengaruh diagnosa medis terhadap kejadian Ventilator Associated Pneumonia (VAP) kecuali diagnosa medis yang berkaitan dengan sistem pernafasan.

\section{KESIMPULAN DAN SARAN}

Kejadian VAP pada pasien yang terpasang ventilasi mekanik yang dilakukan mobilisasi dan fisioterapi dada sesuai dengan kebiasaan ruangan yaitu sebesar (70\%) lebih tinggi dari kejadian VAP pada pasien yang terpasang ventilasi mekanik yang dilakukan mobilisasi dan fisioterapi dada sesuai dengan SOP yaitu sebesar $40 \%$. Namun tidak terdapat perbedaan yang signifikan antara mobilisasi (ambulasi) dan fisioterapi dada yang dilakukan sesuai kebiasaan ruangan dengan mobilisasi dan fisioterapi dada sesuai dengan SOP ( $p$ $>0,05)$.

Diharapkan bagi profesi keperawatan untuk dapat mengaplikasikan penggunaan pedoman mobilisasi (ambulasi) dan fisioterapi dada pada pasien yang terpasang ventilasi mekanik. Bagi institusi RS. Dr. M. Djamil Padang dalam pembuatan standar operasional prosedur (SOP), agar dapat menjelaskan lamanya waktu pemberian tindakan untuk dari masing-masing tindakan tersebut. Selanjutnya, bagi penelitian berikutnya diharapkan mengadakan penelitian pada sampel berpasangan dengan karakteristik yang serupa pada kedua kelompok terutama umur dan diagnosa penyakit.

\section{DAFTAR PUSTAKA}

Brunner \& Suddarth, (2002). Keperawatan Medikal Bedah. edisi 8. Vol 2. Jakarta: EGC

Dahlan, Z. (2006). Tinjauan Ulang Masalah Pneumonia yang didapat di rumah sakit. Bandung: Tidak dipublikasikan

Dudut. (2003). Asuhan Keperawatan Klien dengan Ventilasi Mekanik. FK USU: Tidak dipublikasikan

Hudak \& Gallo. (1997). Keperawatan Kritis Pendekatan Holistik. Edisi VI. Jakarta: EGC

Medical Record Rumah Sakit Umum Pusat D. M. Djamil Padang 2008

Potter dan Perry. (2006). Buku Ajar Fundamental Keperawatan, Konsep, Proses, dan Praktik. Edisi 4. Jakarta: EGC

Regina. (2006). Infeksi Nasokomial Pneumonia. Bandung: Tidak dipublikasikan 
Sedono. R. (2007). Pencegahan Ventilator Associated Pneumonia. Disampaikan pada Kursus Dasar ke 4 Pengendalian Infeksi Nosokomial di RSPAD Gatot Subroto. Jakarta: Tidak dipublikasikan

Tietjen, dkk. (2004). Panduan Pencegahan Infeksi Untuk Fasilitas Kesehatan dengan Sumber Daya Terbatas. Jakarta: Yayasan Bina Pustaka Sarwono Prawiroharjo

Wahyuningsih. (2005). Pedoman Perawatan Pasien. Jakarta: EGC

Yuldanita. (2009). Hubungan Pengetahuan dan Sikap Perawat dengan Tindakan Pencegahan Ventilator Associated Pneumonia di Unit Perawatan Intensif RS. Dr. M. Djamil Padang. Skripsi Unand 